\title{
Research on the Influence of Export Trade Dependence on Industry Capital Structure
}

\author{
Huiyue Liu \\ Shenzhen Tourism College \\ Jinan University \\ Shenzhen, Guangdong, China 518053
}

\author{
Gege Zhang \\ Shenzhen Tourism College \\ Jinan University \\ Shenzhen, Guangdong, China 518053
}

\begin{abstract}
The development of China's manufacturing industry is in a critical period of upgrading and transformation of industrial structure. This paper selects the data of 16 industries in China from 2007 to 2015 to test the degree of dependence on export trade and industry capital Structural adjustment. The results show that the industrial capital structure is positively correlated with the dependence on the export trade, and the non-linear "inverted U" relationship exists between them. However, the degree of dependence of export trade on the capital structure of different debt maturity is not the same. In the short term, there is a positive correlation and a negative correlation in the long term. There is an "inverted $U$ " relationship between the degree of dependence on exports and the level of short-term debt, but it is a "U" relationship with the level of long-term debt.
\end{abstract}

Keywords-export trade dependence; capital structure; manufacturing industry

\section{INTRODUCTION}

Since the reform and opening up, China's export trade develops rapidly, and the export scale further expands, driving the sustainable growth of China's economy. With the rapid development of economic globalization and market economy, China's export enterprises are facing more and more intense competition, and the strong export performance has become an important factor affecting the survival and development of enterprises. China's manufacturing industry is known as the pillar of the national economy, with great significance in stimulating economic growth, promoting employment and increasing exports, whose steady and healthy development plays a decisive role in the national economy. The capital structure is directly related to the business performance of enterprises with impact on their asset value and business behavior. Reasonable capital structure plays an important role in the steady growth of an industry. However, problems such as the exchange rate, political risk, information asymmetry, agency costs, competition and conflict with local market faced by the export market have affected the capital

*Fund Project: This study is funded by the Fund Youth Project "China's financial fragility and Financial Risk Management under the Background of Unbalanced Liquidity Structure" (14CJY004) of the National Social Science, the Fundamental Scientific Research Business Fund (22614817) of the Central Universities and the key cultivating research project of High-level University Construction of Guangdong Province. structure of various industries in our country to a certain extent. In the post-financial crisis era, the development of the global economy is still looking for a new equilibrium point. China's economic development is also facing new opportunities and challenges. There is still the problem of structural disequilibrium in the process of the adjustment of industrial economic structure. Such disequilibrium is multidimensional and multi-level, among which the imbalance in import and export trades is an important factor that affects the reasonable use of capital and leads to heterogeneity of industrial development. It is clearly pointed out in the "13th Five Year Plan" to play the role of exports in growth, accelerate the optimization and upgrading of foreign trade, and develop from a large country of foreign trade to a strong country of trade. Therefore, it is of great important theoretical and practical significance to identify the trade dependence for the adjustment mechanism and characteristics of the industrial capital structure.

\section{LITERATURE REVIEW}

As the core of modern enterprise financing, tissue of capital structure has always been a hot topic in academic research. Mature theories at present include MM theory, equilibrium theory, pecking-order financing theory and so on. Modigliani and Miller (1958) published the theory that the capital structure of enterprises has nothing to do with the enterprise value in the friction-free market condition with complete information and no income tax. The trade-off theory of Mayers (1984) argued that, in the presence of corporate income tax, corporate liabilities will increase the enterprise value due to the tax shield effect, and the maximum value of the enterprise should be realized on the basis of balancing the debt interest to cver tax and cost. Myers and Majluf (1984) suggested in the pecking-order financing theory that corporate finance generally follows the order of internal financing, debt financing and equity financing, and enterprises with strong profitability have more financing channels and lower debt ratios. In recent years, the study of capital structure provides more specific theoretical and empirical results, and there is more exploration of factors that affect the capital structure.

With the increase of international trade activities, in recent years, the academic community is more concerned about the relationship between national trade liberalization 
and capital structure. It is generally believed that trade dependence affects the capital structure of enterprises, while a consensus on the direction of influence has not been reached. Most studies of trade liberalization or internationalization on the capital structure focus on the debt structure of multinational enterprises. The level of debt held by transnational enterprises is significantly lower than that of domestic enterprises, and there is a negative correlation between export and capital structure. Lee and Kwok (1988), Chen et al. (1997), when comparing the capital structure of multinational and domestic enterprises, argued that multinational enterprises face greater agency costs and risks, which gives them a lower leverage than domestic enterprises. The study of Doukas and Pantzalis (2003) also validated this theory. Reeb et al. (1998) found that transnational enterprises are more vulnerable to the negative effects caused by exchange rate movements and political problems in a changing international market, with higher possibility of financial crisis. Desai et al. (2008) argued that multinational enterprises are exposed to higher political risks, with less influence than domestic enterprises. Wright et al. (2005) argued that multinational enterprises face economic and cultural differences among countries, with increased risk of information asymmetry and debt financing costs, and lower leverage levels. Burgman (1996) suggested that higher monitoring costs make multinational enterprises tend to reduce debt levels. As mentioned above, a consensus of relationship between the degree of trade liberalization and the capital structure has not yet been reached, and most studies are enterprise studies based on micro-level. This paper tries to identify the adjustment mechanism of capital structure based on the pecking-order financing theory. Generally speaking, high trade dependence has more financing demand, therefore the capital structure shall also be higher. In an incompletely relevant market, international diversified operation will increase cash flow of the enterprise and reduce the volatility of earnings, resulting in reduction in debt financing costs and bankruptcy risk, and a corresponding increase in debt levels. Therefore, this paper presents Assumption 1.

Assumption 1: trade dependence will trigger the adjustment mechanism of the industrial capital structure, and the export trade dependence is positively related to the debt level of industrial assets.

Although most studies have shown that trade dependence is negatively correlated with the capital structure of transnational enterprises, the academic community still remains controversial on this conclusion. According to the study of Fatemi (1984), Agmon and Lessard (1997), diversified operation of multinational enterprises has a stable cash flow, reduces the volatility of earnings, the company's operating risks and expected bankruptcy costs, and has the ability to bear higher debt levels, so internationalization should have a positive impact on the capital structure. Lewellen (1971) and Shapiro (1978) argued that the incompletely relevant cash flow generated by corporate business in diversified operation provides a guarantee for improving debt financing capacity and reduces debt financing costs, and companies will choose a higher leverage level, which was also validated by Shapiro (2008). In addition, according to the pecking-order financing theory, with the rapid growth of export enterprises, there are more financing needs, therefore the export performance and capital structure should be positively related. Singh and Nejadmalayeri (2004) found in the in study of French sample companies that the higher degree of trade liberalization, the higher level of debt. At the same time, there is a non-linear "inverted U" relationship between the degree of internationalization and short-term debt financing.

As people pay more attention to internationalization, Chinese scholars have also begun to study the relevance between internationalization and capital structure. Zhu Qin and Cheng Huifang (2002) proposed that multinational enterprises have a higher agency cost which leads to a capital structure with lower debt ratio. Fu Jianshe and Fan $\mathrm{Yi}$ (2006) proposed that the international operation of multinational enterprises has positive and negative effects on the cost of its debt financing, while the international environmental uncertainty and the lack of international capital market have a greater impact. The cost of debt financing is higher than that of domestic enterprises, and therefore the leverage is low. Yang Xiaoli (2009) founded in the study on the factors affecting the capital structure China's multinational enterprises that, the corporate politics or strategic objectives of "Go Out" Policy are greater than the economic goal, and internationalization has no significant impact on capital structure. Considering that with the deepening of the degree of internationalization, it may have a non-linear relationship with the capital structure, as demonstrated by the study results of Singh and Nejadmalayeri (2004), there is a non-linear "inverted U" relationship between the degree of trade liberalization and the short-term debt financing level. Mansi and Reeb (2002) found that although the degree of internationalization is positively related to corporate leverage, it is not a monotonous relationship. Export enterprises face greater exchange rate and political risk, and the agency costs and bankruptcy costs are higher, with higher debt financing costs, so the debt level will be reduced. This paper presents Assumption 2.

Assumption 2: There is a non-linear relationship between trade dependence and industrial capital structure, and there is an "inverted U" relationship between the two.

From the existing research status of the literature, a unified conclusion on the relationship between trade liberalization and the capital structure has not yet been reached, and more research conclusions tend to argue that there is a negative correlation between trade dependence and capital structure. China's academic community has limited research on this field, from the perspective of empirical analysis, there is little study on the effect of trade dependence on the capital structure. In addition, the existing literature focuses on transnational enterprises, and lacks empirical research on the capital structure of the industry's macro environment. With the deepening of internationalization, it becomes a strategic measure of more enterprises for survival and development to enter the international market, and strong export performance plays a 
crucial role in stimulating economic development. This paper attempts to use the panel data regression model with 16 industrial enterprises above designated size in the manufacturing industry in China as object, to analyze the relationship between trade dependence and adjustment of industrial capital structure, and enrich the relevant research in this field.

\section{DATA AND MODEL}

\section{A. Research Samples and Data Sources}

According to the industry classification method and the availability of data in the database of the National Bureau of Statistics, this paper chooses 16 industrial enterprises above designated size in the manufacturing industry as the research object, including agricultural and sideline food processing industry, food manufacturing industry, tobacco manufacturing industry, textile industry, leather, feather (down feather) and their products, wood processing and wood, bamboo, rattan, palm, grass products, furniture manufacturing, printing and recording media reproduction, oil processing, coking and nuclear fuel processing industry, chemical raw materials and chemical product manufacturing, pharmaceutical manufacturing, chemical fiber manufacturing, non-metallic mineral product manufacturing industry, ferrous metal smelting and rolling processing industry, non-ferrous metal smelting and rolling processing industry, paper making and paper product industry. These industries differ in export performance and profitability, but differ little in international trade risks and policies. Based on the availability of data, we selected 2007 to 2015 as study interval. The data is from the database of National Bureau of Statistics. The data samples are initially processed and calculated.

\section{B. Model Setting and Variable Definition}

There are three main types of analytical variables in the empirical analysis adopted in this paper: the explained variable is the capital structure, ie, the asset-liability ratio (TD), expressed by dividing the total liabilities by the total assets; the explaining variable is the export ratio (EXP), expressed by the ratio between export value and the total sales, meanwhile, in order to test the nonlinear relationship between trade dependence and capital structure, the square (EXP2) of EXP is used in this paper to represent the degree of trade dependence in the industry.

For the capital structure is affected from various aspects, in order to improve the accuracy of the research results, this paper introduces a group of influential factors commonly used in the study of capital structure as control variables, including profitability, tangible assets, industrial scale and risk: (1) profitability (ROA) is the ratio of total profit to total assets. According to the pecking-order financing theory, enterprises with higher profitability have more financing channels to obtain funds, and less demand for debt, so the coefficient is expected to be significantly positive; (2) tangible asset (AT) is dividing the sum of non-current liabilities band inventory by the total assets, as collateral, the tangible asset can reduce the agency cost risk and information asymmetry, reduce the cost of debt financing, and the coefficient of AT is expected to be significantly positive; (3) industrial scale (INSIZE) is the logarithm of industry's total assets; the information asymmetry of large industries will be reduced, and then the level of debt financing is improved, so the coefficient of INSIZE is expected to be positive; (4) risk is one of the important factors of capital structure, the pecking-order financing theory argues that there should be a negative correlation between risk and capital structure, the greater the risk, the greater possibility of bankruptcy. Because the risk can not be measured directly, this paper uses solvency ratio (STR) and ratio of debt paying ability (SOR) to replace risk variables. The ratio of solvency is the ratio of non-current liabilities of enterprises to the owner's equity. The higher the solvency ratio, the higher the risk, and the coefficient of STR is negative; the higher solvency of the enterprise, the stronger ability to perform the pledge, the greater likelihood to obtain debt financing, to the coefficient of SOR is expected to be significantly positive. Variable indexes are shown in "Table I".

TABLE I. ARIABLE NAMES AND DESCRIPTIONS

\begin{tabular}{l|l|l|l|}
\hline & $\begin{array}{l}\text { Variable } \\
\text { name }\end{array}$ & \multicolumn{1}{|c}{$\begin{array}{c}\text { Variable } \\
\text { meaning }\end{array}$} & \multicolumn{2}{|c}{ Variable interpretation } \\
\hline $\begin{array}{l}\text { Explained } \\
\text { variable }\end{array}$ & $T D$ & $\begin{array}{l}\text { Asset- } \\
\text { liability ratio }\end{array}$ & $\begin{array}{l}\text { Total liabilities / total } \\
\text { assets }\end{array}$ \\
\hline $\begin{array}{l}\text { Explanatory } \\
\text { variable }\end{array}$ & $E X P$ & $\begin{array}{l}\text { Export } \\
\text { proportion }\end{array}$ & Export value / total sales \\
\cline { 2 - 5 } & $E X P^{2}$ & $\begin{array}{l}\text { Export ratio } \\
\text { square }\end{array}$ & $\begin{array}{l}\text { (Export value / total } \\
\text { sales)2 }\end{array}$ \\
\hline \multirow{3}{*}{$\begin{array}{l}\text { vantrol } \\
\text { variable }\end{array}$} & ROA & $\begin{array}{l}\text { Net interest } \\
\text { rate }\end{array}$ & Total profit / total assets \\
\cline { 2 - 5 } & LNSIZE & $\begin{array}{l}\text { Tangible } \\
\text { asset }\end{array}$ & $\begin{array}{l}\text { Industrial } \\
\text { scale } \\
\text { inventory) / total assets }\end{array}$ \\
\cline { 2 - 5 } & $S T R$ & $\begin{array}{l}\text { The logarithm of total } \\
\text { assets } \\
\text { ratio }\end{array}$ & $\begin{array}{l}\text { Non - current assets / } \\
\text { owner 's equity }\end{array}$ \\
\cline { 2 - 5 } & $S O R$ & $\begin{array}{l}\text { Debt paying } \\
\text { ratio }\end{array}$ & $\begin{array}{l}\text { Owner 's equity / total } \\
\text { liabilities }\end{array}$ \\
\hline
\end{tabular}

C. Descriptive statistics of variable

The descriptive statistical results of the samples are shown in "Table II".

TABLE II. DESCRIPTIVE STATISTICS OF EACH VARIABLE

\begin{tabular}{l|l|l|l|l}
\hline Variable & $\begin{array}{l}\text { Maximum } \\
\text { value }\end{array}$ & $\begin{array}{l}\text { Minimum } \\
\text { value }\end{array}$ & Mean & $\begin{array}{l}\text { Standard } \\
\text { deviation }\end{array}$ \\
\hline$T D$ & 0.676 & 0.215 & 0.528 & 0.098 \\
\hline$E X P$ & 0.436 & 0.004 & 0.090 & 0.087 \\
\hline$E X P^{2}$ & 0.190 & 0.000 & 0.016 & 0.032 \\
\hline$R O A$ & 0.169 & -0.086 & 0.091 & 0.041 \\
\hline$A T$ & 3.232 & 0.704 & 1.239 & 0.475 \\
\hline$L N S I Z E$ & 11.192 & 7.412 & 9.313 & .949 \\
\hline$S T R$ & 3.644 & 0.477 & 0.991 & 0.600 \\
\hline$S O R$ & 0.464 & 0.003 & 0.220 & 0.107 \\
\hline
\end{tabular}

From the explanatory variables, the mean value of TD is 0.528 , the industry's mean asset-liability ratio reaches $52.8 \%$, 
unevenly distributed among various industries or the same industry in different years. From the explanatory variables, the export proportion (EXP) means the export level of various industries from 2007 to 2015, with a mean value of 0.090 , that is, the export value accounts for about $9 \%$ of total sales. Among them, the maximum value is 0.436 , and the minimum value is 0.004 , between which there is a large gap, reflecting that the differences of export dependency between different industries vary. The difference between the maximum and the minimum values of the net interest rate (ROA) is $25.5 \%$, indicating great difference of assets return rate among various industries.

\section{THE EMPIRICAL RESULTS AND ANALYSIS}

This paper examines the impact and influence of the export trade dependence on the industry capital structure of 16 manufacturing industries in China from 2007 to 2015. First of all, it determines the influence of export trade dependence on the level of asset-liability ratio of the manufacturing industry, and then distinguishes the time limit of the industry capital structure, distinguishes the asset-liability ratio into short-term liability ratio and longterm liability, and determines the influencing mechanism of trade dependence and different time limit of capital structure.

\section{A. The Quantitative Inspection of the Influence of Export \\ Trade Dependence on the Capital Structure of the Manufacturing Industry}

In order to study the assumptions proposed above, this paper inspects the panel data model setting. There are three different regression models for the panel data - OLS mixed model, the fixed effect model (FE) and the random effect model (RE), the most ideal model can be obtained through LR test, B-P test and Hausman test. The inspection results of the influence of export trade liberalization on the capital structure of the manufacturing industry are shown in "Table III".

It can be known from LR test that FE is better than mixed OLS; and it can be known from test for heteroscedasticity that RE is better than mixed OLS. Finally, when comparing FE and RE, it is assumed firstly that RE is better than FE, but Hausman test result rejects the original assumption, and the basic assumption of RE is not met. In summary, the fixed effect model is more convincing than the mixed OLS and random effect model. From the inspection results of the fixed effect, most of the parameters are met at $1 \%$ level, among which the export trade dependence and the industry capital structure are positively related, indicating that the higher degree of export trade liberalization, the higher industry liability level. The results of the empirical test also show that there is an "inverted U" relationship between the export dependence on China's manufacturing industry and the industry capital structure. In the short term, the export dependence will increase the industry's asset-liability ratio, but there is a threshold, after which the industry's debt level declines with the increase of export dependence.
TABLE III. METROLOGICAL INSPECTION OF THE INFLUENCE OF EXPORT TRADE DEPENDENCE ON INDUSTRY CAPITAL STRUCTURE

\begin{tabular}{|c|c|c|c|c|}
\hline \multirow{2}{*}{\multicolumn{2}{|c|}{ Estimation method }} & (1) & (2) & (3) \\
\hline & & $O L S$ & $\overline{F E}$ & $R E$ \\
\hline \multirow{2}{*}{$\begin{array}{l}\text { Explanat } \\
\text { ory } \\
\text { variables }\end{array}$} & $E X P$ & $\begin{array}{r}-0.049 \\
(0.115)\end{array}$ & $\begin{array}{r}0.404 * * * \\
(0.096)\end{array}$ & $\begin{array}{r}0.174 * * \\
(0.085)\end{array}$ \\
\hline & $E X P^{2}$ & $\begin{array}{l}0.378 \\
(0.248)\end{array}$ & $\begin{array}{r}-0.278^{*} * \\
(0.138)\end{array}$ & $\begin{array}{l}0.022 \\
(0.132)\end{array}$ \\
\hline \multirow[t]{5}{*}{$\begin{array}{l}\text { Control } \\
\text { variable }\end{array}$} & $R O A$ & $\begin{array}{r}-0.407 * * \\
(0.158)\end{array}$ & $\begin{array}{c}-0.077 * \\
(0.041)\end{array}$ & $\begin{array}{c}-0.129 * * * \\
(0.044)\end{array}$ \\
\hline & $A T$ & $\begin{array}{l}0.135 \\
(0.105)\end{array}$ & $\begin{array}{l}-0.027 \\
(0.045)\end{array}$ & $\begin{array}{l}0.046 \\
(0.044)\end{array}$ \\
\hline & LNSIZE & $\begin{array}{l}0.002 \\
(0.007)\end{array}$ & $\begin{array}{l}0.004 \\
(0.004)\end{array}$ & $\begin{array}{r}-0.002 \\
(0.003)\end{array}$ \\
\hline & $S T R$ & $\begin{array}{r}0.193 * * \\
(0.079)\end{array}$ & $\begin{array}{r}0.255^{*} * * \\
(0.032)\end{array}$ & $\begin{array}{r}0.269 * * * \\
(0.035)\end{array}$ \\
\hline & $S O R$ & $\begin{array}{c}-0.112 * * * \\
(0.013)\end{array}$ & $\begin{array}{c}-0.145 * * * \\
(0.010)\end{array}$ & $\begin{array}{c}-0.128 * * * \\
(0.008) \\
\end{array}$ \\
\hline $\begin{array}{l}\text { Constant } \\
\text { term }\end{array}$ & cons & $0.528 * * *$ & $0.572 * * *$ & $0.578 * * *$ \\
\hline $\begin{array}{l}\text { Observed } \\
\text { value }\end{array}$ & $\mathrm{N}$ & 144 & 144 & 144 \\
\hline \multicolumn{2}{|l|}{ LR test } & 121.46 & \multicolumn{2}{|c|}{$\begin{array}{l}\text { Fixed effect model is } \\
\text { superior to mixed regression }\end{array}$} \\
\hline \multicolumn{2}{|l|}{ B-P test } & 191.08 & \multicolumn{2}{|c|}{$\begin{array}{l}\text { Random effect model is } \\
\text { superior to mixed regression }\end{array}$} \\
\hline \multicolumn{2}{|c|}{ Hausman test } & 71.52 & \multicolumn{2}{|c|}{$\begin{array}{l}\text { Fixed effect model is } \\
\text { superior to random effect } \\
\text { model }\end{array}$} \\
\hline
\end{tabular}

(19,

B. The Quantitative Inspection of the Influence of Export

Trade Dependence on the Different Debt Maturity

Structure of the Manufacturing Industry

In order to further explore the relationship between export dependency and industry leverage, this paper divides the time limit of debt structure. Short-term liability is indicated by (current liability / total asset), long-term debt is indicated by (non-current liability / total assets). The regression results from panel data regression by respectively replacing them with the total liabilities as explanatory variables are shown in "Table IV".

From the panel data regression equation coefficient table obtained in "Table IV", the correlation between export trade dependence and industry capital structure can be obtained. It can be seen from the comparison that: (1) the export trade dependence has a significant influence on the industry capital structure, but the influences of short-term debt structure and the long-term debt structure are in the opposite directions, the increase in export dependence in the short term will increase the industry's financial leverage ratio, but the correlation coefficient of long-term debt is negative, indicating that the higher the export dependence of the industry, the lower the proportion of long-term debt. (2) from the correlation coefficient of the equation $E X P^{2}$, the estimated value of the parameters of the three equations are significant at the 5\% level. The coefficient values of the total debt level and the short-term debt level of the industry are both negative, indicating that the export dependence has a non-linear effect on the total liabilities and short-term liabilities of the industry, and there is an "inverted U" 
relationship between them, the rise of export dependency will increase the industry's short-term liability level in the short term, but the short-term asset-liability ratio of the industry will also decline after reaching the threshold. There is a " $U$ " relationship between the export dependence and the long-term debt level of the industry, that is, the influence of the export dependence on the industry's long-term asset structure is not obvious in the short term, only when the export dependency continues to increase to the threshold will its increasing effect on the long-term capital structure gradually appear.

TABLE IV. THE QUANTITATIVE INSPECTION OF THE INFLUENCE OF EXPORT TRADE DEPENDENCE ON THE DIFFERENT DEBT MATURITY STRUCTURE OF THE MANUFACTURING INDUSTRY

\begin{tabular}{|c|c|c|c|}
\hline Variable & TD & STD & LTD \\
\hline$E X P$ & $\begin{array}{r}0.404 * * * \\
(0.096)\end{array}$ & $\begin{array}{r}0.543 * * * \\
(0.127)\end{array}$ & $\begin{array}{c}-0.140 * * * \\
(0.035)\end{array}$ \\
\hline$E X P^{2}$ & $\begin{array}{r}-0.278 * * \\
(0.138) \\
\end{array}$ & $\begin{array}{r}-0.414 * * \\
(0.181) \\
\end{array}$ & $\begin{array}{r}0.136 * * * \\
(0.050) \\
\end{array}$ \\
\hline$R O A$ & $\begin{array}{r}-0.077 * \\
(0.041)\end{array}$ & $\begin{array}{r}-0.100 * \\
(0.054)\end{array}$ & $\begin{array}{l}0.023 \\
(0.015)\end{array}$ \\
\hline$A T$ & $\begin{array}{r}-0.027 \\
(0.045)\end{array}$ & $\begin{array}{r}-0.039 \\
(0.059)\end{array}$ & $\begin{array}{l}0.012 \\
(0.016)\end{array}$ \\
\hline INSIZE & $\begin{array}{l}0.004 \\
(0.004)\end{array}$ & $\begin{array}{l}0.009 * \\
(0.005)\end{array}$ & $\begin{array}{c}-0.005 * * * \\
(0.001)\end{array}$ \\
\hline$S T R$ & $\begin{array}{r}0.255^{* * * *} \\
(0.032)\end{array}$ & $\begin{array}{r}-0.037 \\
(0.043)\end{array}$ & $\begin{array}{r}0.292 * * * \\
(0.012)\end{array}$ \\
\hline$S O R$ & $\begin{array}{c}-0.145^{* * * *} \\
(0.010)\end{array}$ & $\begin{array}{c}-0.166^{* * * *} \\
(0.013)\end{array}$ & $\begin{array}{r}0.021 * * * \\
(0.003)\end{array}$ \\
\hline cons & $0.572 * * *$ & $0.515 * * *$ & $0.057 * * *$ \\
\hline $\mathrm{N}$ & 144 & 144 & 144 \\
\hline R2 & 0.882 & 0.823 & 0.881 \\
\hline
\end{tabular}

\section{CONCLUSION}

This paper takes 16 industries in the country from 2007 to 2015 as samples, the industry capital structure is the explained variable, and the export trade dependence is the explanatory variable. Meanwhile, profitability, tangible assets, industry size, risk and other control variables are used to explore the influence of export trade dependence on the industry capital structure, and the conclusions are as follows:

There is a significant positive correlation between the industry capital structure and the export trade dependence. In the incompletely relevant market, the international diversified operation will bring about the increase of enterprises' cash flow, reduce the volatility of the income, and reduce the debt financing cost and the bankruptcy risk, which enables them to have the ability to take on higher debt levels. This is consistent with the study results of Fatemi (1984), Agmon and Lessard (1997), and Shapiro (2008). When inspecting the possible non-linear relationship between export dependence on capital structure, the results of this paper show that there is a significant "inverted U" structure between the export trade dependence and industry capital structure, that is, the export dependence will increase the asset-liability ratio in the short term, but there is a threshold, after which the industry's debt level declines with the increase in export dependence.

At the same time, this paper deeply studies with different debt maturity structure as the explanatory variables respectively. The conclusion of the study shows that the export trade dependence has a significant influence on the industry capital structure, but the influences of short-term debt structure and the long-term debt structure are in the opposite directions, in the short term, there is positive correlation, in the long term, there is negative correlation. The non-linear influence of the export dependence on the total liabilities of the industry and the short-term liabilities are in the same direction, in an "inverted U" relationship, with a "U" relationship with the industry's long-term debt level.

In the context of economic globalization, the dependence of China's industries on the export market increases year by year, the internationalization has an important impact on the industry capital structure, and the export industry's capital structure shall be optimized from the perspective of trade liberalization. Firstly, in the premise that the government supports the export of industries, credit support is provided to encourage banks or non-bank financial institutions to reduce lending rates and solve the cash flow difficulties for our exporters and help them grow and develop international markets. The form of export credit is innovated to enriched, to provide financing facilities and make exporters get multi-channel financing. In addition, the government should establish a strict export credit mechanism, on the one hand, it is conducive to safeguarding the financing of export enterprises, optimize the capital structure, on the other hand, it can also make our credit market safely and healthily develop.

\section{REFERENCES}

[1] Agmon T, Lessard D. Investor Recognition of Corporate International Diversification:Reply[J]. The Journal of Finance, 1981,36(1):191-192.

[2] Burgman T A. An Empirical Examination of Multinational Corporate Capital Structure[J]. Journal of International Business Studies, 1996, 27(3):553-570.

[3] Chen C J P, Cheng C S A, He J, et al. An Investigation of the Relationship between International Activities and Capital Structure[J] Journal of International Business Studies, 1997, 28(3):563-577.

[4] Doukas J A, Pantzalis C. Geographic diversification and agency costs of debt of multinational firms[J]. Journal of Corporate Finance, 2003, 9(1):59-92.

[5] Fatemi A M. Shareholder Benefits from Corporate International Diversification[J]. The Journal of Finance, 1984, 39(5):1325-1344.

[6] Lantz P. Capital structure with risky foreign investment[J]. Journal of Financial Economics, 2017.

[7] Lee K C, Kwok C C Y. Multinational Corporations vs. Domestic Corporations: International Environmental Factors and Determinants of Capital Structure[J]. Journal of International Business Studies, 1988, 19(2):195-217.

[8] Lewellen W G. A PURE FINANCIAL RATIONALE FOR THE CONGLOMERATE MERGER[J]. The Journal of Finance, 1971, 26(2):521-537.

[9] Mansi S A, Reeb D M. Corporate International Activity and Debt Financing[J]. Journal of International Business Studies, 2002, 33(1):129-147. 
[10] Modigliani F, Miller M H. Corporate Income Taxes and the Cost of Capital: A Correction[J]. American Economic Review, 1963, 53(3):433-443.

[11] Modigliani F, Miller M H. THE COST OF CAPITAL, CORPORATION FINANCE AND THE THEORY OF INVESTMIENT[C]. Comment, American Economic Review. 1959:261-297.

[12] Myers S C, Majluf N S. Corporate financing and investment decisions when firms have information that investors do not have[J]. Social Science Electronic Publishing, 1984, 13(2):187-221.

[13] Reeb D M, Kwok C C Y, Baek H Y. Systematic Risk of the Multinational Corporation[J]. Journal of International Business Studies, 1998, 29(2):263-279.

[14] Shapiro A C. Financial Structure and Cost of Capital in the Multinational Corporation[J]. Journal of Financial and Quantitative Analysis, 1978, 13(2):211-226

[15] Shapiro A C. Multinational financial management[M]. John Wiley \& Sons, 2008.

[16] Singh M, Nejadmalayeri A. Internationalization, capital structure, and cost of capital: evidence from French corporations [J]. Journal of Multinational Financial Management, 2004, 14(2):153-169.

[17] Wright M, Filatotchev I, Hoskisson R E, et al. Strategy Research in Emerging Economies: Challenging the Conventional Wisdom *[J]. Journal of Management Studies, 2005, 42(1):1-33.

[18] Fu Jianshe, Fanyi. Analysis of the Deterministic Mechanism of Capital Structure of Multinational Enterprises [J]. Journal of Hubei Institute for Nationalities (Philosophy and Social Sciences Edition), 2006, 24 (6): 157-160

[19] Yang Xiaoli.Study on Influencing Factors of Capital Structure of Chinese Transnational Enterprises [J]. Modern Management Science, 2010 (9): 71-73.

[20] Zhu Qin, Cheng Huifang. Analysis of Determinants of Capital Structure of Multinational Enterprises Based on Trade-off Model [J]. Journal of Central University of Finance and Economics, 2002 (12): 66-70. 